\title{
TOMOGRAPHIC ANALYSIS OF C7, T1 AND T2 VERTEBRAE ANATOMY IN CHILDREN
}

\author{
ESTUDO TOMOGRÁFICO DAS VÉRTEBRAS \\ C7, T1 E T2 EM CRIANÇAS
}

\author{
Gabriela Estefanía Delgado Cabrera ${ }^{1}$ (1), Marcelo Giacomin da Fonseca ${ }^{1}$ (1), Mauro Costa Morais Tavares Junior ${ }^{1}$ (1), \\ Raphael Martus Marcon ${ }^{1}$ (1), Alexandre Fogaça CRISTANTE ${ }^{1}$ (i), Olavo Biraghi Letaif ${ }^{1}$ (1)
}

1. Universidade de São Paulo, Faculty of Medicine, Hospital das Clínicas, Institute of Orthopedics and Traumatology, HC-FMUSP, São Paulo, SP, Brazil.

\section{ABSTRACT}

Objective: To evaluate and compare anatomical measurements of C7, T1 and T2 vertebrae in children from 3 to 12 years of age to provide useful epidemiological data for determining the safe anatomical margin for transpedicular and translaminar fixation with screws in this population. Methods: This observational retrospective cross-sectional study evaluated 76 computed tomography scans obtained over 6 months, analyzing the following parameters: the angle of attack, length, thickness and diameter of the pedicle; and the angle of attack, length and thickness of the lamina. Results: The lamina length and thickness, as well as pedicle length varied in size according to age. Although the angle of attack was similar across different ages, age-dependent variation occurred in the T1 vertebra. Conclusion: Screws with a $3.5 \mathrm{~mm}$ diameter are safe to use in the $\mathrm{C} 7$ and $\mathrm{T} 2$ pedicles, while the $\mathrm{T} 1$ pedicle allows the introduction of larger screws ranging from 3.5-4.5 mm in diameter. In the lamina, $3.5 \mathrm{~mm}$ screws are safe for use only in children older than 7 years. However, each case should be analyzed individually, with the present study not aiming to replace the preoperative use of CT. Level of Evidence III, Retrospective comparative study.

Keywords: Tomography, X-Ray Computed. Cervical Vertebrae. Retrospective Studies.
RESUMO

Objetivo: Avaliar e comparar as medidas anatômicas das vértebras C7, T1 e T2 em crianças de 3 a 12 anos de modo a determinar margens seguras para fixação transpedicular e translaminar com parafusos nessa população. Métodos: Estudo transversal retrospectivo observacional. Um total de 76 tomografias computadorizadas foram analisadas em um período de 6 meses. Os seguintes parâmetros foram analisados: ângulo de ataque, comprimento, espessura e diâmetro do pedículo, comprimento e espessura da lâmina. Resultados: O comprimento e espessura da lâmina bem como o comprimento do pedículo aumenta em tamanho conforme a idade. Enquanto o ângulo de ataque permanece estável conforme variação de idade; variação dependente da idade ocorre somente na vértebra T1. Conclusão: Parafusos com diâmetro de $3.5 \mathrm{~mm}$ podem ser inseridos de maneira segura nos pedículos de C7 e T2. Já no pedículo de $T 1$ pode-se inserir parafusos com medidas de 3.5 a $4.5 \mathrm{~mm}$ de diâmetro de maneira segura. Na lâmina, parafusos de $3.5 \mathrm{~mm}$ podem ser usados de maneira segura somente em crianças maiores de 7 anos. No entanto, cada caso deve ser analisado de maneira individualizada, e o presente estudo não objetivo substituir o uso de tomografia computadorizada no pré-operatório. Nível de Evidência III, Estudo Comparativo Retrospectivo.

Descritores: Tomografia Computadorizada por Raios X. Vértebras Cervicais. Estudos Retrospectivos.

Citation: Cabrera GED, Fonseca MG, Tavares MCM Jr., Marcon RM, Cristante AF, Letaif OB. Tomographic analysis of C7, T1 and T2 vertebrae anatomy in children. Acta Ortop Bras. [online]. 2021;29(3):153-158. Available from URL: http://www.scielo.br/aob.

\section{INTRODUCTION}

Having anatomical structures of unique importance, the cervicothoracic region presents a shift from the more mobile vertebral segments of the cervical spine to the more rigid segments or the thoracic spine; thus, during surgical treatments performed in this region, it is important to use implants that provide adequate mechanical support, rigidity, stability, and secure fixation. As spinal disorders often occur in this region, including fractures, tumors and deformities, having a detailed knowledge of vertebral morphology becomes essential for any surgical approach using pedicular or translaminar screws at the $\mathrm{C} 7, \mathrm{~T} 1$ or T2 level.

As reported by previous studies, ${ }^{1-3}$ even within a population comprising individuals with similar ages but different ethnicities, the anatomical dimensions of the vertebral body, spinal canal and transverse diameter of the pedicle can vary. For this reason, tomographic analysis is of great assistance during preoperative planning, helping minimize surgical complications, such as incorrectly positioned implants, violation of the vertebral cortex or neurovascularlesions. ${ }^{4}$

\section{All authors declare no potential conflict of interest related to this article.}


Since surgical transpedicular fixation in pediatric patients, in whom structures have smaller sizes, entails technical difficulties, ${ }^{5}$ it is necessary and useful to evaluate the angle of attack, length and thickness of cervicothoracic junction vertebrae structures. Also relevant is to correlate anatomic measurements with commercially available pedicular and translaminar implants and their screws due to the high prevalence of use, the association with fixation rigidity and the higher rates of arthrodesis consolidation ${ }^{5-7}$ of the screws themselves.

Based on the above, the present study used computed tomography $(\mathrm{CT})$ to evaluate the pedicle and lamina anatomy of the $\mathrm{C}$, $\mathrm{T} 1$ and T2 vertebrae in children from 3 to 12 years of age. The aim was to provide a published record of epidemiological data obtained in this pediatric population, which can be useful for determining the safety margins of transpedicular and translaminar fixation in cases that may require implants.

\section{MATERIALS AND METHODS}

The study evaluated 76 computed tomography (CT) scans, routinely performed for polytrauma cases during the 6-month period from July 2018 to December 2018, following the institutional protocol. To increase data veracity, ${ }^{8}$ two researchers conducted the analysis of this continuously selected sample simultaneously. Morphometric analysis was performed using the iSite PACS Philips Healthcare Informatics $\AA$ program.

The selected cases were separated in two groups according to the patients' age, with cutoff age based on the fusion period of the primary ossification centers of C7, T1 and T2 vertebrae, complete at 8 years old.$^{9}$ Group 1 included patients from 3 to 7 years of age, and Group 2 patients from 8 to 12 years of age. Each group was then subdivided into 2 subgroups according to gender: Female and Male. Ethnicity and race were not investigated due to extensive miscegenation in the studied population.

Exclusion criteria included patients with cervical or thoracic vertebrae fracture, a diagnosis of cervical or thoracic spinal deformity or malformation, poor quality imaging tests, infections, tumors, or previous surgery in the cervical or thoracic spine.

Pedicle measurements were obtained as follows: ${ }^{10}$

1) Angle of attack: measured on axial CT as the angle between a line parallel to the spinous process and a line parallel to the long axis of the pedicle (Figure 1).

2) Pedicle diameter: measured on coronal CT as the distance between the medial and lateral cortices of the pedicle in the isthmus (Figure 2).

3) Length: measured on axial CT as the distance between the posterior cortex of the pedicle and the posterior longitudinal ligament along the axis of the pedicle (Figure 3).

4) Thickness: measured on axial CT as the distance between the lateral and medial cortices of the pedicle in the isthmus (Figure 3).

Lamina measurements were obtained as follows: ${ }^{11}$

1) Angle of attack: measured on axial CT between a line parallel to the laminar cortex and a line parallel to the longitudinal axis of the spinous process (Figure 4).

2) Length: measured on axial CT as the distance between the posterior and anterior limit of the lamina (Figure 5)

3) Thickness: measured on axial CT as the distance between the medial and lateral cortex of the lamina in a thin slice (Figure 5).

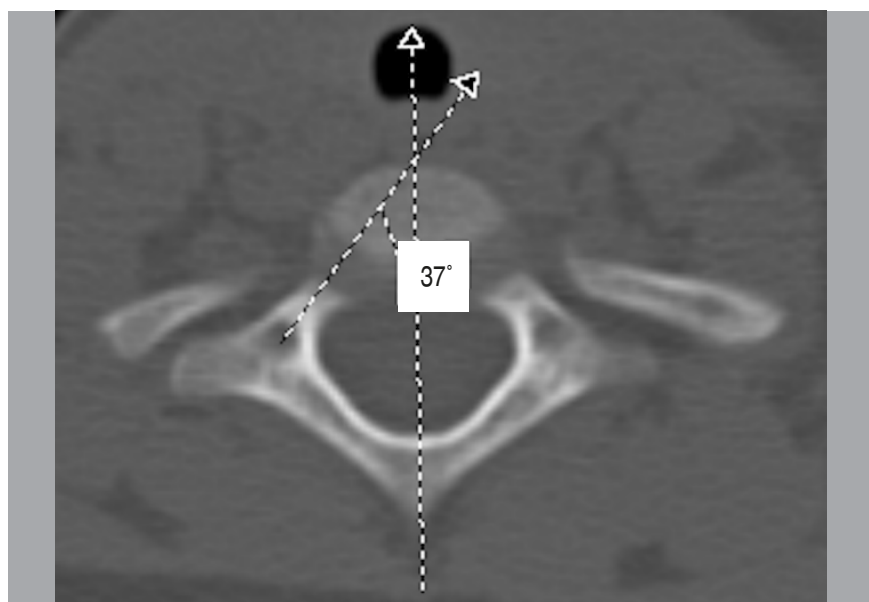

Figure 1. Angle of attack measurement.

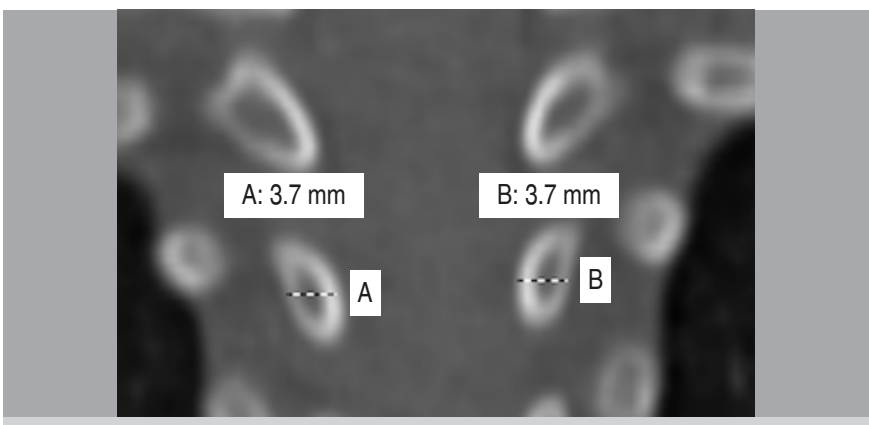

Figure 2. Pedicle diameter measurement.

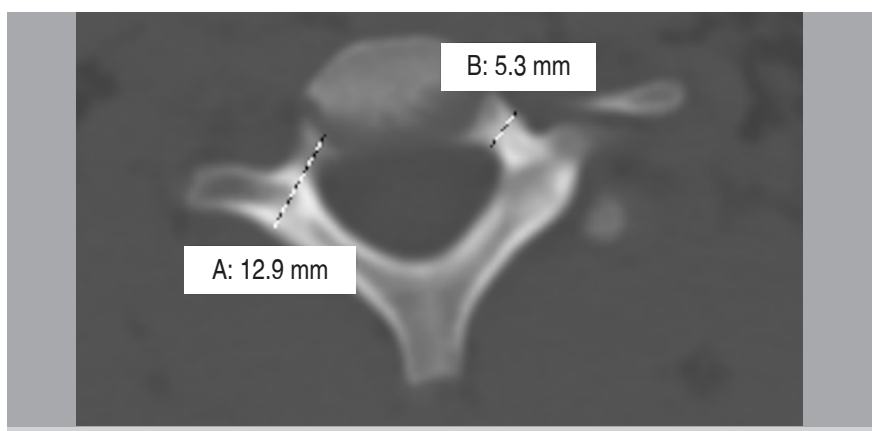

Figure 3. Measurements of a) pedicle length and b) pedicle thickness.

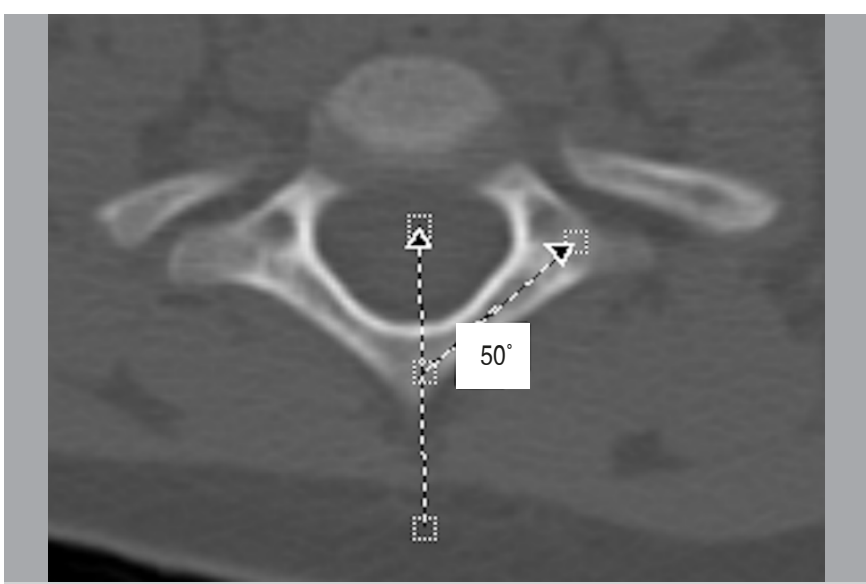

Figure 4. Angle of attack measurement. 


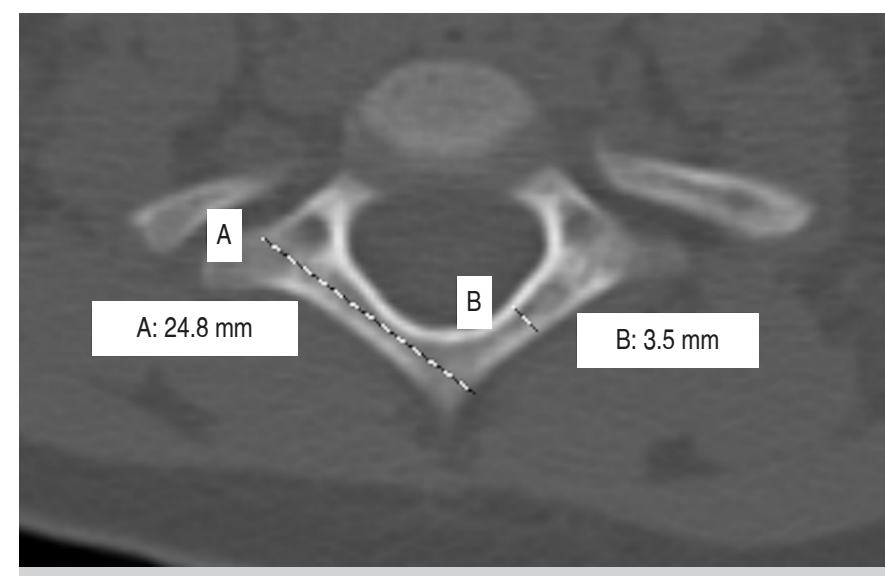

Figure 5. Measures of a) lamina length and b) lamina thickness.

Each vertebra measurement is described by age and gender using means \pm standard deviations; estimated ranges are shown with $95 \%$ normal distributions. ${ }^{12}$ All measures were compared among groups using variance analysis with 2 factors (gender and age) followed by multiple Bonferroni ${ }^{13}$ corrections when significant.

The point numbers are described in quadrants and compared among these using generalized estimation equations, with an interchangeable correlation matrix between sides and quadrants, a Poisson marginal distribution and identity bond function ${ }^{14}$ followed by multiple Bonferroni ${ }^{13}$ comparisons, to determine in which quadrants the differences occurred. All analyses were performed using IBM-SPSS for Windows version 20.0 software; data tabulation used the Microsoft Excel 2003 software. The tests adopted a $5 \%$ significance level.

\section{RESULTS}

After applying the exclusion and inclusion criteria, the study sample comprised 76 patients with cervicothoracic junction CT scans. Group 1 (patients from 3 to 7 years of age) included 46 individuals; Group 2 (patients from 8 to 12 years of age) included 30 individuals. The children's mean age was 7.1 years old ( $S D=3.2$ years), with most being between 3 and 7 years old (60.5\%) and male (68.4\%) (Table 1).

Table 1. Characteristics of the children evaluated.

\begin{tabular}{c|c}
\hline Variable & Description $(\mathbf{n}=\mathbf{7 6})$ \\
\hline Age (years), mean \pm SD & $7.1 \pm 3.2$ \\
\hline Age group, $\mathbf{n}(\%)$ & \\
\hline 3 to 7 years & $46(60.5)$ \\
\hline 8 to 12 years & $30(39.5)$ \\
\hline Gender, $\mathbf{n}(\%)$ & \\
\hline Female & $24(31.6)$ \\
\hline Male & $52(68.4)$ \\
\hline
\end{tabular}

\section{C7 vertebra}

Lamina length in C7 was statistically higher only in children from 8 to 12 years of age, regardless of gender $(p<0.05)$ (Table 2$)$.

\section{T1 vertebra}

The angle of attack and pedicle length were significantly higher in Group 2 than in Group 1, regardless of gender ( $p=0.006$ and $p=0.008$, respectively). The lamina length was also significantly higher in older children, regardless of gender $(p<0.001)$ (Table 3$)$.

Table 2. Description and comparison of $\mathrm{C} 7$ vertebra measurements by age group and gender.

\begin{tabular}{|c|c|c|c|c|c|c|c|}
\hline \multirow{2}{*}{ Variable } & \multicolumn{2}{|c|}{3 to 7 years of age } & \multicolumn{2}{|c|}{8 to 12 years of age } & \multirow{2}{*}{ p Age group } & \multirow{2}{*}{ p Gender } & \multirow{2}{*}{ p Interaction } \\
\hline & Female $(n=15)$ & Male $(n=31)$ & Female $(n=9)$ & Male $(n=21)$ & & & \\
\hline \multicolumn{8}{|l|}{ Pedicle } \\
\hline mean $\pm S D$ & $33.4 \pm 5.3$ & $35.2 \pm 5.5$ & $34.4 \pm 6.1$ & $38.2 \pm 7$ & & & \\
\hline NR (95\%) & $(23-43.8)$ & $(24.5-45.9)$ & $(22.5-46.4)$ & $(24.5-51.8)$ & & & \\
\hline Length & & & & & 0.432 & 0.202 & 0.226 \\
\hline NR (95\%) & $(10.2-15.9)$ & $(10.4-15.8)$ & $(10.2-14.6)$ & $(10.7-15.8)$ & & & \\
\hline Thickness & & & & & 0.222 & 0.256 & 0.611 \\
\hline mean $\pm \mathrm{SD}$ & $3.2 \pm 0.7$ & $3.4 \pm 0.8$ & $3.4 \pm 0.5$ & $3.7 \pm 1$ & & & \\
\hline NR $(95 \%)$ & $(1.9-4.6)$ & $(1.7-5)$ & $(2.5-4.3)$ & $(1.8-5.6)$ & & & \\
\hline Diameter* & & & & & 0.883 & 0.458 & 0.186 \\
\hline \multicolumn{8}{|l|}{ Lamina } \\
\hline Angle of attack & & & & & 0.658 & 0.690 & 0.337 \\
\hline mean $\pm \mathrm{SD}$ & $48.4 \pm 3$ & $47.8 \pm 3.4$ & $47 \pm 3.6$ & $48.4 \pm 5.2$ & & & \\
\hline NR (95\%) & $(42.6-54.2)$ & $(41.2-54.4)$ & $(39.9-54.1)$ & $(38.2-58.5)$ & & & \\
\hline Length & & & & & 0.010 & 0.346 & 0.981 \\
\hline mean $\pm S D$ & $28.1 \pm 2.4$ & $28.8 \pm 2.5$ & $30 \pm 3.2$ & $30.7 \pm 3.2$ & & & \\
\hline NR (95\%) & $(23.4-32.8)$ & $(23.8-33.7)$ & $(23.8-36.2)$ & $(24.3-37)$ & & & \\
\hline Thickness & & & & & 0.269 & 0.910 & 0.332 \\
\hline mean $\pm \mathrm{SD}$ & $2.2 \pm 0.6$ & $2.3 \pm 1$ & $2.6 \pm 0.6$ & $2.4 \pm 0.6$ & & & \\
\hline NR (95\%) & $(1-3.3)$ & $(0.5-4.2)$ & $(1.4-3.8)$ & $(1.2-3.6)$ & & & \\
\hline
\end{tabular}

ANOVA with two factors; NR: normal range; * two cases were not evaluated for this parameter 
Table 3. Description and comparison of T1 vertebra measurements by age group and gender.

\begin{tabular}{|c|c|c|c|c|c|c|c|}
\hline \multirow{2}{*}{ Variable } & \multicolumn{2}{|c|}{3 to 7 years of age } & \multicolumn{2}{|c|}{8 to 12 years of age } & \multirow{2}{*}{ p Age group } & \multirow{2}{*}{ p Gender } & \multirow{2}{*}{\begin{tabular}{|c|}
$\mathbf{p}$ \\
Interaction
\end{tabular}} \\
\hline & Female $(n=15)$ & Male $(n=31)$ & Female $(n=9)$ & Male $(n=21)$ & & & \\
\hline \multicolumn{8}{|l|}{ Pedicle } \\
\hline Angle of attack & & & & & 0.006 & 0.794 & 0.974 \\
\hline NR (95\%) & $(19.8-41.3)$ & $(16.2-43.9)$ & $(20-51.7)$ & $(18.6-52.2)$ & & & \\
\hline Length & & & & & 0.008 & 0.531 & 0.100 \\
\hline mean $\pm S D$ & $13.7 \pm 1.3$ & $14.2 \pm 1.6$ & $15.8 \pm 1.6$ & $14.7 \pm 2.6$ & & & \\
\hline Thickness & & & & & 0.290 & 0.617 & 0.607 \\
\hline mean $\pm \mathrm{SD}$ & $3.4 \pm 0.8$ & $3.7 \pm 1$ & $3.8 \pm 0.9$ & $3.8 \pm 0.8$ & & & \\
\hline NR $(95 \%)$ & $(1.9-5)$ & $(1.6-5.7)$ & $(2.1-5.5)$ & $(2.2-5.4)$ & & & \\
\hline Diameter* & & & & & 0.267 & 0.448 & 0.436 \\
\hline mean $\pm S D$ & $3.7 \pm 1$ & $3.7 \pm 0.8$ & $4.2 \pm 1$ & $3.8 \pm 0.9$ & & & \\
\hline NR (95\%) & $(1.8-5.6)$ & $(2.1-5.4)$ & $(2.1-6.2)$ & $(2-5.7)$ & & & \\
\hline NR (95\%) & $(41.5-54.5)$ & $(38.5-54.7)$ & $(40.9-52.9)$ & $(38.4-57.5)$ & & & \\
\hline Length & & & & & $<0.001$ & 0.948 & 0.273 \\
\hline mean \pm SD & $25.8 \pm 2.4$ & $26.7 \pm 2.9$ & $29.7 \pm 3.4$ & $28.9 \pm 3.5$ & & & \\
\hline NR $(95 \%)$ & $(21.1-30.6)$ & $(21.1-32.3)$ & $(23-36.3)$ & $(22-35.7)$ & & & \\
\hline Thickness & & & & & 0.064 & 0.539 & 0.978 \\
\hline mean \pm SD & $2.8 \pm 0.6$ & $2.9 \pm 0.8$ & $3.1 \pm 0.7$ & $3.3 \pm 0.9$ & & & \\
\hline NR $(95 \%)$ & $(1.6-3.9)$ & $(1.3-4.5)$ & $(1.8-4.5)$ & $(1.6-5)$ & & & \\
\hline
\end{tabular}

ANOVA with two factors; NR: normal range; * two cases were not evaluated for this parameter

T2 vertebra

Lamina length and thickness were significantly higher in children from 8 to 12 years of age than in children from 3 to 7 years of age, regardless of gender ( $p<0.001$ and $p=0.003$, respectively) (Table 4).
T2 mean pedicle length was significantly higher in 8-12 years old female children than in 3-7 years old female children $(p=0.012)$ and 3-7 years old male children $(p=0.046)$ (Table 5).

Table 4. Description and comparison of T2 vertebra measurements by age group and gender.

\begin{tabular}{|c|c|c|c|c|c|c|c|}
\hline \multirow{2}{*}{ Variable } & \multicolumn{2}{|c|}{3 to 7 years of age } & \multicolumn{2}{|c|}{8 to 12 years of age } & \multirow{2}{*}{ p Age group } & \multirow{2}{*}{ p Gender } & \multirow{2}{*}{$\underset{\text { Interaction }}{\mathbf{p}}$} \\
\hline & Female $(n=15)$ & Male $(n=31)$ & Female $(n=9)$ & Male $(n=21)$ & & & \\
\hline Angle of attack & & & & & 0.054 & 0.842 & 0.851 \\
\hline NR (95\%) & $(11.8-30.1)$ & $(10-31.8)$ & $(16.3-31.4)$ & $(11.8-34.8)$ & & & \\
\hline Length & & & & & 0.003 & 0.309 & 0.028 \\
\hline mean $\pm S D$ & $13.9 \pm 1.6$ & $14.5 \pm 1.6$ & $16.3 \pm 1.5$ & $14.8 \pm 2.1$ & & & \\
\hline mean $\pm S D$ & $3 \pm 0.7$ & $3.1 \pm 0.9$ & $3.1 \pm 0.5$ & $3.4 \pm 0.8$ & & & \\
\hline NR $(95 \%)$ & $(1.6-4.3)$ & $(1.3-5)$ & $(2.1-4)$ & $(1.8-5)$ & & & \\
\hline Diameter $^{*}$ & & & & & 0.113 & 0.544 & 0.825 \\
\hline mean $\pm S D$ & $3.2 \pm 0.8$ & $3.4 \pm 0.9$ & $3.7 \pm 1.3$ & $3.8 \pm 1.2$ & & & \\
\hline NR (95\%) & $(1.6-4.8)$ & $(1.7-5.1)$ & $(1.1-6.3)$ & $(1.4-6.2)$ & & & \\
\hline \multicolumn{8}{|l|}{ Lamina } \\
\hline Length & & & & & $<0.001$ & 0.571 & 0.652 \\
\hline mean $\pm S D$ & $21.9 \pm 1.6$ & $22.5 \pm 2$ & $24.3 \pm 2.2$ & $24.3 \pm 2.9$ & & & \\
\hline NR (95\%) & $(18.8-25)$ & $(18.6-26.4)$ & $(19.9-28.6)$ & $(18.6-30.1)$ & & & \\
\hline Thickness & & & & & 0.003 & 0.574 & 0.468 \\
\hline mean $\pm S D$ & $2.5 \pm 0.6$ & $2.8 \pm 0.8$ & $3.2 \pm 0.8$ & $3.2 \pm 0.7$ & & & \\
\hline NR (95\%) & $(1.3-3.7)$ & $(1.2-4.4)$ & $(1.7-4.8)$ & $(1.7-4.7)$ & & & \\
\hline
\end{tabular}


Table 5. Comparison of T2 pedicle length by age group and gender.

\begin{tabular}{|c|c|c|c|c|c|c|}
\hline \multirow{2}{*}{\multicolumn{2}{|c|}{ Comparison }} & \multirow{3}{*}{$\begin{array}{c}\text { Mean difference } \\
-0.54 \\
\end{array}$} & \multirow{3}{*}{$\begin{array}{c}\text { Standard error } \\
0.55\end{array}$} & \multirow{3}{*}{$\begin{array}{c}\begin{array}{c}p \\
\text { Inferior }\end{array} \\
>0.999 \\
\end{array}$} & \multicolumn{2}{|c|}{$\mathrm{Cl}(95 \%)$} \\
\hline & & & & & \multirow{2}{*}{$\begin{array}{c}\text { Superior } \\
-2.02\end{array}$} & \multirow[b]{2}{*}{0.94} \\
\hline Female from 3 to 7 years & Male from 3 to 7 years & & & & & \\
\hline Female from 3 to 7 years & Female from 8 to 12 years & -2.34 & 0.73 & 0.012 & -4.32 & -0.35 \\
\hline Female from 3 to 7 years & Male from 8 to 12 years & -0.90 & 0.59 & 0.776 & -2.49 & 0.69 \\
\hline Male from 3 to 7 years & Female from 8 to 12 years & -1.80 & 0.66 & 0.046 & -3.59 & -0.02 \\
\hline Male from 3 to 7 years & Male from 8 to 12 years & -0.36 & 0.49 & $>0.999$ & -1.69 & 0.97 \\
\hline Female from 8 to 12 years & Male from 8 to 12 years & 1.44 & 0.69 & 0.246 & -0.44 & 3.31 \\
\hline
\end{tabular}

Multiple Bonferroni comparisons.

\section{DISCUSSION}

Performing transpedicular and translaminar fixation on the cervicothoracic junction using screws is becoming a more widespread practice. Hence, why having a detailed knowledge of vertebral morphology becomes essential to select the correct surgical approach for using pedicular or laminar screws in any type of disorder at the $\mathrm{C} 7, \mathrm{~T} 1$ or T2 level. Discrepancies between the actual thickness of the pedicle or lamina and the diameters of commercially available screws can lead to fractures on the walls of these structures and implant failure, ${ }^{15}$ or even compromise the safety of the procedure, causing neurological risk. Our study is pioneering in presenting a combined evaluation of the pedicle and lamina anatomies at the cervicothoracic junction in children. To our knowledge, this is the first simultaneous analysis in the scientific literature that describes the pediatric $\mathrm{C} 7, \mathrm{~T} 1$ and T2 pedicles and laminae and their correlations with the use of commercially available screws.

After analyzing the collected data, we observed that the length of $\mathrm{T} 1$ and $\mathrm{T} 2$ pedicles differed significantly depending on age, similar to results found by a previous study. ${ }^{8}$ In our study, the T2 pedicle was longer in female patients. This result is consistent with Kretzer et al., ${ }^{16}$ who showed that pedicle length depended on the patient's gender $(p<0.001)$; but differs from the findings of Chen et al., ${ }^{17}$ who reported that pedicle length was higher in male patients than in female patients. Such discrepancy may be due to differences peculiar to the ethnicity and age of each analyzed population, as Chen et al.'s ${ }^{17}$ study focused on adults instead of children.

Regarding the $\mathrm{C} 7$ vertebra, our results show an age-dependent difference in lamina length, similar to the findings by Kanna et al. ${ }^{18}$ Onibokun et al., ${ }^{19}$ in turn, found no difference in pedicle length according to age.

Compared to the study by Marchese et al., ${ }^{11}$ which found significant differences in the length and width of the T1 lamina according to age, our results show that while the $\mathrm{T} 1$ lamina length was significantly higher in older children regardless of gender $(p<0.001)$, there was no such difference in lamina thickness. As for the T2 vertebra, we found significant differences in lamina length and thickness between age groups, similar to the findings of Molina et al. ${ }^{5}$

Our data allow us to affirm that screws with a $3.5 \mathrm{~mm}$ diameter can be safely applied in C7 and T2 pedicles, while T1 supports larger pedicle screws ranging from 3.5 to $4.5 \mathrm{~mm}$ in diameter. These findings are similar to those of Rekate et al., ${ }^{20}$ who concluded that pedicle fixation could be safely applied in children over 4 years old. Our results also resemble those by Ranade et al.;1 the authors showed that the pedicles of patients younger than 8 years old can safely receive 3.5-5.5 mm screws. Hassan et al., ${ }^{22}$ however, observed that applying fixation with pedicular screws of diameter greater than $3.0 \mathrm{~mm}$ was unsafe in children and adolescents younger than 18 years old. These divergent findings may be due to the smaller stature of Asian patients. ${ }^{8}$

Regarding translaminar fixation, we conclude that it is possible to safely use $3.5 \mathrm{~mm}$ screws only in children older than 7 years old, finding similar to that of a previous study. ${ }^{5}$ Our results clash, however, with those presented by Kretzer et al., ${ }^{23}$ who found no size-related limitations for introducing translaminar screws. Since the study published by Kretzer et al. ${ }^{23}$ included patients aged 41.7 +/- 19.6 years, the age difference between samples could explain this divergence.

Our findings suggest that it is crucial to analyze the vertebral anatomy based on computed tomography during the surgical planning of pathologies that affect a child's spine. But this is a retrospective study of a sample composed mainly of male children under 8 years of age (hence, prior to the complete ossification of the vertebrae); thus, future studies are needed to confirm the data obtained here and to eventually collect additional information on cervicothoracic junction fixation in the pediatric population.

\section{CONCLUSION}

Our results allow us to conclude that lamina length and thickness, as well as pedicle length increase with age. We found a significant age-dependent variation in the angle of attack when considering only the T1 pedicle. Based on the morphologies of the studied vertebrae, screws with $3.5 \mathrm{~mm}$ diameter are safe to use in the C7 and T2 pedicles, while the T1 pedicle allows for screws up to 4.5 $\mathrm{mm}$ in diameter. As for translaminar fixation, the present study conclude that it is only safe to use screws thicker than $3.5 \mathrm{~mm}$ in children older than 7 years old. However, we must analyze each case individually, with the present study not aiming to replace the preoperative use of CT.

AUTHORS' CONTRIBUTIONS: Each author contributed individually and significantly to the development of this article. GEDC: literature review and project design, data collection and analysis, manuscript writing; MGF: literature review and project design, data collection and analysis, manuscript writing; MCMTJ: literature review and project design, data collection and analysis, manuscript writing; RMM: final review of the literature and project, data analysis and manuscript review; AFC: final review of the literature and project, data analysis and manuscript review; OBL: study design, data analysis and final review of the manuscript.

\section{REFERENCES}

1. Datir SP, Mitra SR. Morphometric study of the thoracic vertebral pedicle in an Indian population. Spine (Phila Pa 1976). 2004;29(11):1174-81.

2. Kim NH, Lee HM, Chung IH, Kim HJ, Kim SJ. Morphometric study of the pedicles of thoracic and lumbar vertebrae in Koreans. Spine (Phila Pa 1976). 1994; 19(12):1390-4.
3. Tan SH, Teo EC, Chua HC. Quantitative three-dimensional anatomy of cervical, thoracic and lumbar vertebrae of Chinese Singaporeans. Eur Spine J. 2004;13(2):137-46.

4. Pihlajamäki $H$, Myllynen $P, B$ B̈stman $O$. Complications of transpedicular lumbosacral fixation for non-traumatic disorders. J Bone Joint Surg Br. 1997;79(2):183-9. 
5. Molina C, Sciubba DM, Chaput C, Tortolani PJ, Jallo GI, Kretzer RM. A computed tomography-based feasibility study of translaminar screw placement in the pediatric thoracic spine. J Neurosurg Pediatr. 2012;9(1):27-34.

6. Feng ZH, Li XB, Tian NF, Sheng SR, Li YM, Phan K, et al. The technique of cortical bone trajectory screw fixation in spine surgery: a comprehensive literature review. AME Med J. 2018;3(1):8.

7. Puvanesarajah V, Liauw JA, Lo SF, Lina IA, Witham TF. Techniques and accuracy of thoracolumbar pedicle screw placement. World J Orthop. 2014;5(2):112-23.

8. Zheng C, Huang Q, Hu Y, Wang X, Chen W. Computed tomographic morphometry of thoracic pedicles: safety pedicle parameter measurement of the Chinese immature thoracic spine. Int Orthop. 2009;33(6):1663-8.

9. Thompson JC. Netter Atlas de Anatomia Ortopédica. Rio de Janeiro: Elsevier; 2012.

10. Vaccaro AR, Rizzolo SJ, Allardyce TJ, Ramsey M, Salvo J, Balderston RA, et al. Placement of pedicle screws in the thoracic spine. Part I: Morphometric analysis of the thoracic vertebrae. J Bone Joint Surg Am. 1995;77(8):1193-9.

11. Marchese LRD, Letaif OB, Marcon RM, Cristante AF, Oliveira RP, Barros Filho TEP. Tomographic analysis of $\mathrm{t}-1$ vertebra to insert laminar screws in children from 0 to 12 years. Coluna/Columna. 2015;14(4):304-7.

12. Kirkwood BR, Sterne JAC. Essential Medical Statistics. Massachusetts: Blackwell Science; 2006

13. Neter J, Kutner MH, Nachtsheim CJ, Wasserman W. Applied Linear Statistical Models. Ilinois: Richard D. Irwing; 1996.

14. McCullagh P, Nelder JA. Generalized Linear Models. London: Chapman \& Hall; 1989.

15. Misenhimer GR, Peek RD, Wiltse LL, Rothman SL, Widell EH Jr. Anatomic analysis of pedicle cortical and cancellous diameter as related to screw size. Spine (Phila Pa 1976). 1989;14(4):367-72.
16. Kretzer RM, Chaput C, Sciubba DM, Garonzik IM, Jallo GI, McAfee PC, et al. A computed tomography-based morphometric study of thoracic pedicle anatomy in a random United States trauma population. J Neurosurg Spine. 2011;14(2):235-43.

17. Chen Y, Zeng J, Guan J, Guo Y, Wang X, Yao G, et al. Reformatted computed tomographic evaluation of the thoracic pedicle in a Chinese population for the surgical application of transpedicular screw placement. Surg Radiol Anat. 2010;32(5):463-8.

18. Kanna PR, Shetty AP, Rajasekaran S. Anatomical feasibility of pediatric cervical pedicle screw insertion by computed tomographic morphometric evaluation of 376 pediatric cervical pedicles. Spine (Phila Pa 1976) 2011;36(16): 1297-304.

19. Onibokun A, Khoo LT, Bistazzoni S, Chen NF, Sassi M. Anatomical considerations for cervical pedicle screw insertion: the use of multiplanar computerized tomography measurements in 122 consecutive clinical cases. Spine J. 2009;9(9):729-34.

20. Rekate HL, Theodore N, Sonntag VK, Dickman CA. Pediatric spine and spinal cord trauma. State of the art for the third millennium. Childs Nerv Syst. 1999; 15(11-12):743-50

21. Ranade A, Samdani AF, Williams R, Barne K, McGirt MJ, Ramos G, et al. Feasibility and accuracy of pedicle screws in children younger than eight years of age. Spine (Phila Pa 1976). 2009;34(26):2907-11.

22. Hassan E, Liau KM, Ariffin I, Yusof AH. Internal morphometry of thoracic pedicles in the immature spine. Spine (Phila Pa 1976). 2010;35(13):1253-6.

23. Kretzer RM, Chaput C, Sciubba DM, Garonzik IM, Jallo GI, McAfee PC, et al. A computed tomography-based feasibility study of translaminar screw fixation in the upper thoracic spine. J Neurosurg Spine. 2010;12(3):286-92. 